\title{
'A Storm on the Horizon' \\ Discomforting Democracy and the Feeling of Fairness
}

\section{ANN PELLEgRINI}

NEW YORK UNIVERSITY

\section{- OverTURE}

'There's a bright golden haze on the meadow, there's a bright golden haze on the meadow.' So begin the opening lines of Oklahoma, the 1943 Richard Rodgers and Oscar Hammerstein musical that is widely credited as the first full-blown 'book musical'. The original Broadway production ran for an astonishing 2212 performances, and the play was adapted into an Academy Award-winning film in 1955, during the height of the Cold War. The Oklahoma Territory portrayed in the Rodgers and Hammerstein musical was riven by conflicts between farmer and cowman. Could these rivals become friends? Yes! They can! Peace and social harmony win out, and the community forged by play's end shines as golden-bright as the Oklahoma sun. And yet, the histories of so many are left off-stage, out of view. Oklahoma sanitises the story of American expansion, presenting a liberal fable of democratic harmony bursting forth amidst social difference. ${ }^{1}$ The violent death of 'Pore Jud Fry' is but an afterthought, the man who killed him quickly acquitted so that he can enjoy his honeymoon with his new bride. As for the violent displacement 
of Native Americans into and from the 'unassigned lands' that became Oklahoma? Within the musical world of Oklahoma, it is no thought at all. Ultimately, the beautiful American morning the show celebrates requires setting some others beyond the pale.

Although Oklahoma may not be accurate as history, its exclusions, the stories it does not or cannot tell, nonetheless testify to the failures of liberal tolerance to make room for wider forms of social difference. Making social space for difference does not mean that everyone has to be friends. Indeed, the widening I will argue for in this essay both requires and produces an agonistic public square. This is democracy as discomfort. However, democracy does not require that we agree with each other, let alone like each other. As recent events in the real-life Oklahoma suggest, agonistic democratic pluralism is an unfinished project.

\section{-'SAVE OuR STATE'}

In November 2010, voters in the state of Oklahoma overwhelmingly approved a ballot measure that bans judges from 'considering or using Shariah Law' when making a ruling. State Question 755-also known as SQ 755, the Shariah Amendment, the Oklahoma International Law Amendment and, most apocalyptically, the 'Save Our State' Amendment-garnered the support of 70 per cent of voters. In addition to amending the state constitution to ban judicial consideration of Shariah law, the measure also more broadly forbids courts from 'considering or using international law'.

This coupling of Shariah law and international law requires some preliminary explanation and conceptual untangling. The section of SQ 755 that forbids a state court from 'considering or using international law' reflects a broader conservative distrust of any citation of international law as amounting to a violation of American sovereignty. This hostility is seen even among some jurists themselves. For example, Supreme Court Justice Antonin Scalia has been a very public critic of reference to foreign law in US courts. One notable case in point is his withering dissent in Lawrence v. Texas, the 2003 Supreme Court case that found laws against consensual 'homosexual sodomy' to be unconstitutional. The vote in that landmark case was six to three. Justice Scalia voted in the minority to uphold anti-sodomy statutes. His dissent was wide-ranging, but he was particularly exercised by the majority 
opinion's approving reference to a 1981 decision by the European Court of Human Rights holding that 'laws proscribing [consensual homosexual conduct] were invalid under the European Convention on Human Rights'. ${ }^{2}$

This hostility to international law is hardly some quirk of Justice Scalia, but can be seen also in the US Congress's unwillingness to ratify any number of international treaties. Moreover, such opposition cuts across simplistic partisan political distinctions and extends a long tradition of American exceptionalism, whose shadow gives cover to nativist suspicions of 'foreigners'. A state amendment to ban a court's consideration of foreign laws could probably survive constitutional scrutiny and be upheld by the courts. It is the singling out of a specific religion-Islam-that poses constitutional issues, as I will shortly argue. In fact, two other US states, Tennessee and Louisiana, both passed more neutrally worded 'anti-foreign law' bills in 2010, which made no reference to any religion, precisely in order to avoid this legal problem. Legalisms aside, we should not lose sight of the ugly challenge to democratic values posed by these carefully worded bans on foreign law. The contemporary organised movement to pass such bans is in fact the 'polite' face of what is, at its foundation, an anti-Muslim campaign. ${ }^{3}$ Whether or not a law passes constitutional muster does not tell us the whole story. Thus, even as I do address the constitutional dilemmas posed by anti-Shariah laws below, the larger concern of this essay is on the extra-legal effects of such bans, how they simultaneously illuminate and animate anti-Muslim bias as well as reveal broader problems raised by the US discourse of tolerance.

\section{-CHRISTIAN DOMINANCE AND US SECULARISM}

As of this writing, Oklahoma's ban on the consideration of Shariah law and any foreign law has not gone into effect. Within days of the measure's passage, US District Judge Vicki Miles-LaGrange granted a preliminary injunction against State Question 755. She was responding to a lawsuit filed by Muneer Awad, executive director of the Oklahoma chapter of the Council on American-Islamic Relations (CAIR). In issuing the injunction, Judge Miles-LaGrange determined that Awad had made a 'preliminary showing' that the Oklahoma amendment violated the First Amendment to the US Constitution. 
The First Amendment begins: 'Congress shall make no law respecting an establishment of religion, or prohibiting the free exercise thereof'. Religious freedom has two components: disestablishment and free exercise, and a lot of ink has been spilled over the relation between these two aspects of religious freedom: how they are related, whether one is more important than the other and how to balance their principles when they seem to conflict. These are not just academic questions. In Love the Sin: Sexual Regulation and the Limits of Religious Freedom, Janet Jakobsen and I argue that it matters a great deal for the practice of democratic social relations whether one sees these two principles as separable or interstructuring. ${ }^{4}$ Public political debates over the meaning of religious freedom in the United States all too often produce the following balkanisation: proponents of more religion (really, more Christianity) in US public life and in government lean heavily on the free exercise component and underplay disestablishment. Conversely, many secularists-not all secularists, to be sure, but many-stress the absolute separation of church and state and minimise free exercise. In contrast, Jakobsen and I see disestablishment as the structuring condition for free exercise. Otherwise, those who are religiously different or not religious at all may well find their lives not simply less admired and valued than those who belong to the dominant religion; they may find they have diminished legal status.

Jakobsen and I are sympathetic to those who are nervous about an overpresence of religion in American public life; however, we do not think the problem is religion per se, with the banishment of religion from public life as the only remedy. Rather, the problem is one of social dominance. ${ }^{5}$ Currently, the religion that enjoys the most room for 'free exercise' in the United States is Christianity. Christianity offers the model for what other religions are supposed to look and feel like, such that even the Supreme Court, the very body charged with interpreting the meaning of disestablishment and free exercise, defaults to Christian-more accurately, to Reformed Protestant-notions of what religion 'is' when deciding whether or not particular religious rights have been violated. ${ }^{6}$ This can work out well if the claimants belong to mainline Protestant denominations, but not so well, if they do not. As conservative legal scholar Frederick Mark Gedicks reports, 'No Jewish, Muslim, or Native American plaintiff has ever prevailed on a free exercise claim 
before the Supreme Court. Fundamentalist Christians and sects outside so-called mainline Protestantism have had only mixed success in seeking exemptions.'7

One of the ways Christian dominance works is that particular Christian practices and ideals can 'float', sometimes being overtly marked as religious, at other times passing as secular, something Jakobsen and I have referred to as 'Christonormativity'. Stephen M. Feldman examines this phenomenon as it has played out in a string of Supreme Court cases concerning religious freedom. Because 'Christian domination is so deeply rooted in American history,' he argues, 'any judicial reliance on tradition or history likely will result in the constitutional approval of Christian practices and values'. ${ }^{8}$ This is not a matter of bad faith (pun intended). The court does not operate in a vacuum, but is itself embedded in the symbols, structures and context of Christian dominance. ${ }^{9}$ How much this situation will change now that there are three Jewish members of the Supreme Court remains to be seen. It would be a mistake, however, to see this Christian bias as arising from any one individual justice's, or particular group of justices', blind spots. The problem emerges from institutional practices, interpretive assumptions and structuring conditions, which reproduce Christian domination. One effect of this persistent Christian bias in judicial decisions-and in legislative policies, as well-is that, as Feldman concludes, 'outgroup religions are more likely to be protected [from discrimination] when their practices and tenets resemble those of Christianity'.10 But, democratic freedom should not require that those who are religiously different be or become the same as the dominant norm in order to be treated as equals before the law. Such a requirement-to become like or like enough-significantly reduces democratic social space not just for being different, but also for performing, enacting, one's difference in public.

The ongoing dominance of Christianity and its default status as the measure of 'the religious' have produced a situation where religious difference is at best seen as at odds with American identity. At worst, it is imagined to be an actual threat to 'traditional' American values, where 'traditional' means Christian, but can be stretched to the hyphenated 'Judeo-Christian' under certain circumstances, as we shall shortly see.

This is precisely the dynamic playing out in the Oklahoma amendment. If enacted, the amendment would establish a class of religious outsiders, whose 
religious practices and social identities are afforded lesser legal protections and public status than their religiously orthodox neighbors. In its preliminary injunction, the district court found that the amendment 'does not have a secular purpose, that its primary purpose inhibits religion, and that it fosters an excessive government entanglement with religion'.11 No compelling state interest was advanced to justify these linked violations of the Establishment Clause. Quite the contrary: despite claims that Question 755 was necessary to 'save our state', proponents of the law could not point to any concrete instances where Shariah law actually had been imposed on Oklahoma citizens, let alone by the courts. In the preliminary hearing conducted by the district court immediately after voter passage of the amendment, Scott Boughton, an assistant attorney general for the state, conceded that he knew of no cases in which Oklahoma courts had in fact invoked Shariah law. And yet, facts were apparently no obstacle, for he persisted in defending the law on behalf of the state.

Muslims are a slim minority in Oklahoma: 30,000 of a total state population of 3.7 million. However, who needs actual Muslims when you have the potent figure of 'the Muslim', an all-purpose bogeyman for the American twenty-first century?12 And the dangerous Muslim conjured by the US political imaginary is almost always male; when Muslim women do appear, they do so veiled and victimised-by Muslim men and Shariah law.

Fearmongering rhetoric notwithstanding, the Caliphate is not coming to Oklahoma any time soon, or anywhere else in the US for that matter. But the Oklahoma amendment, if enacted, would have a chilling effect on the free exercise rights of Muslims in that state. As law professor Aziz Huq explained in the New York Times:

A butcher would no longer be able to enforce his contract for halal meatcontracts that, like deals for kosher or other faith-sanctioned foods, are regularly enforced around the country. Nor could a Muslim banker seek damages for violations of a financial instrument certified as 'Sharia compliant' since it pays no interest. ${ }^{13}$

This burden on free exercise thus violates the second component of First Amendment religious freedom. To its credit, the Oklahoma district court did not pull its punches in identifying the anti-Muslim bias animating the amendment: the 
'amendment is not facially neutral, discriminates against a specific religious belief, and prohibits conduct because it is undertaken for religious reasons'.14

-THE FRAME OF DIFFERENCE: INSIDERS AND OUTSIDERS TO THE NATION

Most legal analysts agree that the district court's injunction will likely become permanent and will survive appeal. The anti-Shariah amendment is dead, for now, in the state of Oklahoma. More than legal prohibitions are at stake, however. A law does not have to be enforced to have profoundly shaping effects on public debates over insiders and outsiders to the nation. Legislators in six other states are considering similarly worded bans on Shariah law and, as Huq reports, many more (fourteen at this counting) are considering wider bans on use of 'foreign laws'. The public language used in these debates contributes to an atmosphere in which 'Muslim-Oklahoman' or, simply, 'Muslim-American' is an impossible identity. For example, in a June 2010 interview with ABC News (US), state representative Rex Duncan, chair of Oklahoma's House Judiciary Committee and an author of the antiShariah amendment, used a meteorological metaphor to explain the vital need for the law: 'It's not an imminent threat in Oklahoma yet, but it's a storm on the horizon in other states.' 15 Subsequently, in an interview with cable news channel MSNBC, he turned to military metaphors to describe the amendment as a 'a war for the survival of America' and 'a pre-emptive strike' against Islamic law and against 'liberal judges' who want to undermine America's 'founding principles'.16 By 'founding principles', though, Duncan did not mean the Constitution. 'Oklahomans', he continued, 'recognize that America was founded on Judeo-Christian principles.' It is these values the amendment defends, to ensure 'that our courts are not used to undermine those founding principles, and turn Oklahoma into something that our founding fathers and our great grandparents wouldn't recognize'.

In this rhetorical circuit, Duncan ties a knot between America and particular religious values ('Judeo-Christian') and links social recognition to a matter of family resemblance: what 'our founding fathers and our great grandparents' would or would not recognise. The conjoined language of family and of self-defence-Save Our State-recodes the amendment. To its legislative backers, like Duncan, and to the overwhelming number of Oklahomans who voted for it, State Question 755 was 
not about discrimination against Muslims. ${ }^{17}$ It was about defending core American principles. And who'd be against that, except those who are un- or anti-American?

The dense network of ties spun by Duncan-nation = Judeo-Christian = familyproduces powerful affective resonances across ideological and creedal affiliations. ${ }^{18}$ The addition of 'Judeo' is important here, as it further cements the notion that State Question 755 is not religiously discriminatory. First, the hyphenate 'Judeo-Christian' posits a false identity and equality between Judaism and Christianity. ${ }^{19}$ Second, in the specific context of public debates over the place of Muslims in American life, 'Judeo-Christian' effectively triangulates two groups of religious outsidersAmerican Jews and American Muslims-identifying the former as manifesting an acceptable form of religious difference, and setting the latter outside the boundaries of national belonging.

As Jakobsen and I argue in Love the Sin, such acts of naming are part of the process by which the lines between who belongs and who does not are drawn and reinforced. ${ }^{20}$ Public discourse, how we talk about and frame debates over difference, matters; it materialises. Indeed, how we talk about and name 'others' can turn social difference, which is not or need not be a problem, into social division, which is. This is not a recent dilemma, and tolerance is not the solution. Robust democratic engagement that widens the space for difference, rather than requiring those who are different to become more of the same, is.

\section{- WHAT THE CENTRE CANNOT HOLD}

In The Citizen Machine: Governing by Television in 1950s America, Anna McCarthy analyses the emergence of television as a technology of national belonging, tracing how corporations, non-profit foundations, intellectuals, and politicians variously sought to use the new medium to teach citizens how to properly engage in democratic life in the United States during the Cold War. ${ }^{21}$ One of the things McCarthy illuminates is how a centrist language of balance and moderation was deployed by both conservatives and liberals to discredit opposing positions as 'extremist' and over the line. Of course, not every individual or group was equally positioned to have its appeals to centrism credited. In practice, the language of the centre was also a vocabulary of marginalisation that secured the boundaries of the general public by relegating some subjects to its outside. 
In one especially telling incident, McCarthy recounts President Dwight D. Eisenhower's refusal to meet with civil rights leaders after Brown v. Board of Education. In that landmark 1954 case, the Supreme Court held that the racial segregation of public schools was unconstitutional, effectively ending separate but equal as a matter of law. 22 How well this mandate was carried out in practice is a separate issue, especially in light of the court's language in a follow-up hearing, in 1955, to determine how the desegregation should be achieved: namely, 'with all deliberate speed'. This ambiguous language was used by opponents of desegregation to delay implementation of the new policy.

For his part, Eisenhower justified his refusal to meet with civil rights leaders on the grounds that if he met with them he would also have to meet with the Ku Klux Klan, a logic that effectively equated peaceful activists for racial equality with an organisation dedicated to the violent suppression of racial and religious minorities. This equation was utterly of its moment, however. As McCarthy underlines, Eisenhower's appeals to balance and moderation were of a piece with broader Cold War attempts to cultivate a democratic citizenry that was engaged, but not 'extremist'. (Cue Oklahoma's 'Oh, the farmer and the cowman should be friends ... territory folks should stick together, territory folks should all be pals'.) Within this logic, 'extremist' meant 'activist', a logic of equivalence that actually promoted inequality. How so? This equation made it impossible to make important moral and political distinctions between advocates of freedom and equality and advocates of hateful violence.

In Love the Sin, Jakobsen and I discuss this reductionist logic in relation to the structure of tolerance. To be tolerant is to be 'fair and balanced'-and that sounds pretty good, right? Nevertheless, we have to ask, fair and balanced as seen from where or from whose point of view? Although American commonsense prizes and seeks to cultivate tolerance as a response to violence and social division, in practice, tolerance works to affirm existing social hierarchies by establishing an us-them relationship between a dominant centre and those on the margins. Us-them commonly triangulates, as when a dominant centre (also known as the phantom 'general public') distinguishes itself from-and morally elevates itself above-two equally 'extremist' others. This is the dynamic at work in Eisenhower's 'inertial stance on racial equality' (to use McCarthy's language). This stance stakes out a 
middle ground in which a dominant white majority need not move the boundaries of national belonging at all or, at least, can cede as little ground as slowly as possible. When the rhetoric of 'fair and balanced' meets 'with all deliberate speed', expect a stall.

'Fair and balanced' is also the self-serving (and trademarked) slogan of Fox News, which is part of Rupert Murdoch's News Corporation. Fox's claims to be 'fair and balanced' have been extensively challenged by media watchdogs like Fairness and Accuracy in Reporting, but without seeming to dent the news network's popularity. If anything, attacks from the left only embolden Fox's claims to be speaking for 'real' American values. And real American values continue to speak from and to an imagined centre, from President Barack Obama's much-repeated hopes of rising above partisanship, to comedian Jon Stewart's 'call-toreasonableness' via his October 2010 national 'Rally to Restore Sanity', to the American media's two sides to every story approach to complex social controversies. I want to be clear that I am not against 'reasonableness' per se. My concern here is with the way such appeals actually function in the storm of public debates over the boundaries of US public life. This is a rather different 'storm' from the one Duncan worries over. Reasonableness or rationality can also work hand in hand with its ostensible opposite: a mobilisation of public feelings.

\section{-PUBLIC FEELINGS AND THE RHETORIC OF REASONABLENESS}

Consider in this regard the intensely mediatised political tempest over Cordoba House, the proposed Islamic centre in downtown Manhattan. This project has become (un)popularly known as the 'Ground Zero Mosque'-an act of misnaming that stuck and has powered much of the controversy over the proposed building. The language of reasonableness may sound softer and kinder than the blatant Islamaphobia of many of the project's opponents, but it amounts to much the same thing: narrowing the social space available to be and 'do' difference in public. Wading into the controversy, President Obama spoke the language of reason and constitutional history when he declared:

Muslims have the same right to practice their religion as anyone else in this country. That includes the right to build a place of worship and a community center on private property in lower Manhattan, in accordance 
with local laws and ordinances. This is America, and our commitment to religious freedom must be unshakeable. The principle that people of all faiths are welcome in this country, and will not be treated differently by their government, is essential to who we are. The writ of our Founders must endure. 23

Obama made these comments in August 2010, at an official White House event celebrating Ramadan, a White House tradition of hosting an Iftar meal that went back several years and was akin to the way the White House hosted 'Christmas parties, seders, and Diwali celebrations'. In what may at first seem like an aside, in his prepared remarks the President mentioned that he is not the first US president to host a dinner celebrating a Muslim holiday. However, this is more than an historical footnote, given the significant percentage of Americans who suspect that President Barack Hussein Obama is himself a secret Muslim. In any case, neither Obama's remarks nor its careful packaging did anything to tamp down the controversy over the Cordoba House project.

Just the opposite. His remarks immediately drew fire from opponents of Cordoba House. The comments of Congressman Peter T. King, a Republican from the state of New York, were typical of the more 'moderate' criticisms the President received:

President Obama is wrong. It is insensitive and uncaring for the Muslim community to build a mosque in the shadow of Ground Zero. While the Muslim community has the right to build the mosque they are abusing that right by needlessly offending so many people who have suffered so much. The right and moral thing for President Obama to have done was to urge Muslim leaders to respect the families of those who died and move their mosque away from Ground Zero. Unfortunately the President caved into political correctness. ${ }^{24}$

In response to such criticisms, and worrying about anticipated Democratic Party losses (and they did lose big) in the November 2010 midterm elections (the same elections in which Oklahoma voters passed the ban on Shariah), on 14 August, just a day after his rousing remarks at the White House event, Obama clarified his meaning: 'My intention was simply to let people know what I thought, which was that in this country, we treat everybody equally and in accordance with the law, 
regardless of race, regardless of religion. I was not commenting and I will not comment on the wisdom of making the decision to put a mosque there.'25

In both King's criticism and Obama's dancing on a pin response, we see what happens when a call to reasonableness meets up with appeals to public feelings: the feelings of some people must be protected, even if that means running roughshod over the rights of some others. This is so because such debates are conducted under conditions of dominance in which some positions are staked out from the beginning as the mark and measure of both reason and reasonable emotional response. If some Muslims come away with hurt feelings, or even limited free exercise rights (as would be the result if Oklahoma's anti-Shariah amendment were enacted), that is just the price they must pay for (eventual?) acceptance.

Tolerance in this context supports anti-Muslim bias and 'Christo-normativity' in the public square. Tolerance, as Jakobsen and I argue at length in Love the Sin, is in many respects a secular version of religious toleration in which an established church allows dissenters the right to worship without fear of persecution, but withholds from them equivalent public or civic rights and privileges. Although the United States is formally secular-again, the First Amendment promises disestablishment and free exercise of religion-Christianity (Reformed Protestantism) has long functioned as the backdrop against which claims to be a moral person or have values achieve cultural legibility. To put this another way, the Christian assumptions underlying tolerance may also help to make sense of why the anti-Muslim feelings animating public debates over Cordoba House are not seen or experienced as prejudice-at least not from the standpoint of the tolerant centre. For those on the margins of US national belonging, the receiving end of such tolerance may not feel so good.

In the controversy over the 'Ground Zero Mosque', Muslim Americans are not being formally excluded by a democratic majority, as they were by Oklahoma voters. Rather, they are being asked (albeit not so politely) to subordinate their free exercise rights under the First Amendment to the hurt feelings of the rest of America; they are also being called upon to identify with the dominant centre-to feel its pain as their own. This set of substitutions assumes that Muslim-Americans are not already part of the United States and also reveals just how limited are the boundaries of moderation, fairness, and tolerance. 


\section{-CONCLUDING NOTES}

The frame of tolerance-the way it legitimates some actors and their public feelings even as it delegitimates some others-can also help make sense of the morally stupefying equivalence some political pundits and media outlets in the United States made between evangelical Pastor Terry Jones's announced 'International Burn a Koran Day', which was timed to coincide with the ninth anniversary of $9 / 11$, and the planned Cordoba Center. Both came to be represented as actions that were within the First Amendment rights of the groups proposing them but which would be 'hurtful'. As with Eisenhower's refusal to meet with civil rights leaders more than sixty years ago, once again we see how inadequate 'moderating' notions like fair and balanced are to making crucial moral distinctions and creating more democratic social space for being different and 'doing' difference.

In the song with which I began this essay, the hero of Oklahoma proclaims his 'beautiful feelin' that everything's goin' my way'. Democracy, however, is not only about beautiful feelings and having things your way. This is among the reasons we need courts to protect the rights of unpopular minorities from the sentiments of majority rules. However, law is not the only forum, and certainly not the most common one, for democratic engagement with difference. In everyday life, we bump up against each other and may well be discomforted by differences we cannot assimilate or will not understand. But difference is not a problem or 'the' problem to get over. It is rather the very material of our lives with others, and the democratic worlds we may yet make.

Ann Pellegrini is Associate Professor of Performance Studies and Religious Studies at New York University, where she also directs NYU's Center for the Study of Gender and Sexuality. She is the author of Performance Anxieties: Staging Psychoanalysis, Staging Race (1997); Love the Sin: Sexual Regulation and the Limits of Religious Tolerance, co-authored with Janet R. Jakobsen (2004); Queer Theory and the Jewish Question, co-edited with Daniel Boyarin and Daniel Itzkovitz (2003); and Secularisms, co-edited with Janet R. Jakobsen (2008). She is currently completing two new projects: a solo book, Excess \& Enchantment: Queer Performance between 
the Religious and the Secular, and You Can Tell Just by Looking and Twenty Other Myths about LBGT Life and People, co-authored with Michael Amico and Michael Bronski.

\section{-ACKNOWLEDGEMENTS}

The ideas developed in this essay owe an incalculable debt to my long-time writing partner and dear friend Janet Jakobsen; I am so grateful for the ongoing spur of her thought. Jill Casid turned her editorial eye and steadying hand on multiple versions of this essay; it's the better for her touch.

\footnotetext{
-NOTES

${ }^{1}$ For a trenchant analysis of liberalism and the e1athno-racial politics of Oklahoma, see Andrea Most, “'We Know We Belong to the Land": The Theatricality of Assimilation in Oklahoma', in her book Making Americans: Jews and the Broadway Musical, Harvard University Press, Cambridge Mass, 2004), 101-18. 2 See Lawrence et al. v. Texas 539 U.S. 558 [2003], p. 573. Full text of decision available at <http://supreme.justia.com/us/539/558/case.html> (accessed 30 October 2011).

3 See Andrea Elliott, 'The Man Behind the Anti-Shariah Movement', New York Times, 30 July 2011, <http://www.nytimes.com/2011/07/31/us/31shariah.html?_r=1\&ref=andreaelliott> (accessed 30 October 2011).

4 Janet R. Jakobsen and Ann Pellegrini, Love the Sin: Sexual Regulation and the Limits of Religious Tolerance, Beacon Press, Boston, 2004. My discussion of the false opposition between disestablishment and free exercise and how this false opposition actually reinforces Christian dominance draws heavily on chapter four of Love the Sin, 'The Free Exercise of Sex', pp. 103-26.

5 Ibid., pp. 111-12.

6 For an astute discussion of this issue, see Stephen M. Feldman, 'A Christian America and the Separation of Church and State' in Law and Religion: A Critical Anthology, ed. Stephen M. Feldman, New York University Press, New York, 2000, pp. 261-77.

7 Frederick Mark Gedicks, The Rhetoric of Church and State: A Critical Analysis of Religion Clause Jurisprudence, Duke University Press, Durham, 1995, p. 116. Jakobsen and I invoke Gedicks in our discussion of the meaning of government neutrality in the face of religious difference. See Jakobsen and Pellegrini, p. 110. For an important Supreme Court case in which religious practices on the frontiers of Christianity were accorded free exercise protections, see Church of Lukumi Babalu Aye v. City of Hialeah, 508 U.S. 520 (1993), which concerned Santeria, a syncretic Afro-Caribbean religion,

<http://www.oyez.org/cases/1990-1999/1992/1992_91_948> (accessed 8 November 2011).

8 Feldman, p. 262.

9 Ibid., p. 261; Jakobsen and Pellegrini, pp. 3-4.
} 
10 Feldman, p. 266.

${ }^{11}$ Muneer Awad v. Paul Ziriax et al., Case No. CIV-10-1186-M, U. District Court for the Western District of Oklahoma (9 November 2010), p. 6. Text of decision available at

<http://www.politico.com/static/PPM152_101109_shariah_tro.html> (accessed 10 July 2011).

12 See Jasbir Puar and Amit S. Rai, 'Monster, Terrorist, Fag: The War on Terrorism and the Production of Docile Patriots', Social Text, vol. 72, no. 20.3, Fall 2002, pp. 117-48.

${ }^{13}$ Aziz Huq, 'Defend Muslims, Defend America', New York Times, 20 June 2011, p. A-27.

${ }^{14}$ Muneer Awad v. Paul Ziriax et al., Case No. CIV-10-1186-M, US District Court for the Western District of Oklahoma (9 November 2010), p. 7. Text of decision available at <http://www.politico.com/static/PPM152_101109_shariah_tro.html> (accessed 10 July 2011).

15 Joel Siegel, 'Islamic Sharia Law to Be Banned in, ah, Oklahoma', ABC News.com, 14 June 2010, <http://abcnews.go.com/US/Media/oklahoma-pass-laws-prohibiting-islamic-sharia-lawsapply/story?id=10908521> (accessed 8 July 2011).

${ }^{16}$ Qtd. in Jillian Rayfield, ‘Oklahoma State Rep. Aims To Stop “Liberal Judges” From Imposing Sharia Law', TPM LiveWire, 11 June 2010, <http://tpmlivewire.talkingpointsmemo.com/2010/06/oklahomastate-senator-aims-to-stop-liberal-judges-from-imposing-sharia-law.php> (accessed 8 July 2011).

${ }^{17}$ As we have seen, a US District Court judge thought otherwise, and she was instantly attacked by supporters of the amendment as a 'liberal' Clinton appointee.

18 I borrow the term 'resonance' from Linda Kintz's important study Between Jesus and the Market: The Emotions That Matter in Right-Wing America, Duke University Press, Durham, 1997.

${ }^{19}$ For a discussion of the rhetorical work 'Judeo-Christian' has done in US debates and, even, in judicial decisions concerning homosexuality, see Jakobsen and Pellegrini, p. 31.

${ }^{20}$ For a parallel case, see Jakobsen's and my discussion of the Defense of Marriage Act, or DOMA, which President Bill Clinton signed into law in 1996. DOMA forbids federal recognition of same-sex marriage. Supporters of this anti-gay law disclaimed homophobia as a motive; instead, they framed their support as a matter of defending traditional marriage and 'the' American family. See Jakobsen and Pellegrini, $p$. 63. In arguing against difference as a problem and against tolerance as a solution to social division, I am condensing a much longer argument developed in my joint work with Jakobsen in Love the Sin. See especially chapter three, 'What's Wrong with Tolerance?', pp. 45-73.

${ }^{21}$ Anna McCarthy, The Citizen Machine: Governing by Television in 1950s America, The New Press, New York, 2010, p. 16.

22 See Brown v. Board of Education, 349 U.S. 294 (1955), <http://www.nationalcenter.org/cc0725.htm> (accessed 10 July 2011).

${ }^{23}$ Qtd at <http://swampland.time.com/2010/08/13/obama-breaks-his-silence-on-cordoba-house/> (accessed 10 July 2011). 
${ }^{24}$ Edward Wyatt, '3 Republicans Criticize Obama's Endorsement of Mosque', New York Times, 14

August 2010, <http://www.nytimes.com/2010/08/15/us/politics/15reaction.html> (accessed 11 July 2011).

25 Karen Tumulty and Michael D. Shear, 'Obama: Backing Muslims' right to build NYC mosque is not an endorsement', Washington Post, 15 August 2010, <http://www.washingtonpost.com/wpdyn/content/article/2010/08/14/AR2010081401796.html> (accessed 10 July 2011). 